\title{
Pathogenicity Test and Anastomosis Group of Rhizoctonia solani the Causal Organism of Stem Canker and Black Scurf Disease of Potato in Egypt
}

\author{
Mohamed A. Abdel-Sattar ${ }^{1}$, Hanan El-Marzouky ${ }^{1}$ and Usama E. Ibrahim ${ }^{2 *}$ \\ ${ }^{1}$ Department of Botany, Faculty of Agriculture, Suez Canal University, Ismailia, Egypt. \\ ${ }^{2}$ CentralAdministration of Plant Quarantine, Ministry of Agricultural, Giza, Egypt
}

Received: $10 / 1 / 2017$

\begin{abstract}
Stem canker and black scurf caused by Rhizoctonia solani Kuhn is considered the most destructive disease and reduce productivity of potato. Pathogenicity test of 12 isolates of $R$. solani obtained from two governorates, ElSharkiya (New El-Salhia region) and Ismailia (El-Shabab region) revealed that all isolates were pathogenic, however isolate No.RS7 was the most virulent isolate in the development of the stem canker and black scurf disease. Molecular technique using PCR applied to determine anastomosis group of isolate No. RS7 showed that this isolate belong to AG3.
\end{abstract}

Keywords: Anastomosis group, Molecular technique, Rhizoctonia solani, Stem canker and black scurf, Pathogenicity test, PCR

\section{INTRODUCTION}

Potato (Solanum tuberosum L.) is one of the most important crops in Egypt as well as all over the world and produces a tuber very rich in starch that it ranks as the world's fourth most paramount food crop, after maize, wheat and rice (Cunnington, 2008). A recent special report by the Food and Agriculture Organization of the United Nations (FAO) highlighted the potato crop as "a vital part of the global food system, and will play an ever greater role in strengthening world food security and alleviating poverty" (Anonymous, 2009).

Stem canker and black scurf caused by $R$. solani Kuhn is considered the most destructive disease, particularly in warm - climate countries and warm sandy soils of temperate regions. Rhizoctonia isolates both multinucleate and binucleate species which are divided into anastomosis groups (AGs). Presently, the multinucleate species of $R$. solani Kuhn (teleomorph: Thanatephorus cucumeris (Frank) Donk.) are divided into 14 anastomosis groups (Tuncer and Eken, 2013): AG-1 to AG-10, AG-BI Sneh et al. (1991), AG-11 Carling et al. (1994), AG-12 Carling et al. (1999) and AG-13 Carling et al. (2002). Each AG has either host specific or with a wide host ranges (Carling et al., 2002; Ogoshi, 1987). For example AG-2 is associated with diverse host plants, but AG 8 is more specifically on cereals. AG-3 is divided into two genetically different subgroups, AG 3 PT associated with potatoes and AG-3 TB on tobacco (Woodhall et al., 2008). Rhizoctonia solani AG-3 PT reduces tuber quality by producing sclerotia (black scurf) on progeny potato tubers. The pathogen also can infect underground organs (stems, stolons and roots), which affects crop yield, tuber size and number (ElBakali and Martin, 2006). In addition to those typical symptoms $R$. solani is associated with several types of blemishes on potato tubers (Fiers et al., 2010). This investigation aims to determine the pathogenicity test of $R$. Solani isolates obtained from two governorates, El-Sharkiya (New El-Salhia region) and Ismailia (El-Shabab region) in the events of stem canker and black scurf on potatoes and determine anastomosis group of aggressive isolate.

\section{MATERIALS AND METHODS}

\section{Isolation $\&$ identification of the pathogen}

For fungal isolation, collected samples of potato were washed carefully under running tap water to remove the adjacent soil particles followed by sterile water, and then was dried between two sterilized filter papers. Infected parts were cut using sterilized scalpel into small pieces $(1 \mathrm{~cm})$, then surface sterilized by immersing in sodium hypochlorite $(1 \%)$ for three minutes subsequently rinsed with sterile water several times. This was followed by soaking in $70 \%$ ethanol for one minute. After rinsing with sterile water three times, $1 \mathrm{~cm}$ infected (stem or tubers) dried segments were sterilized, transferred to plates of PDA or CYA (Czapek yeast extract agar) supplemented with rose bengal $(1 / 15)$ and chloramphenicol $(50 \mathrm{ppm})$ to suppress bacterial growth then incubated at $28 \pm 2^{\circ} \mathrm{C}$ for 7 days. Plates were daily observed for mycelial growth. Hyphal tips of mycelium emerging from the infected pieces were transferred to fresh plates of PDA and CYA.

Pure cultures of $R$. solani isolates were preliminary identified by visual observation of macromorphological characters using naked eye, and the identification was confirmed microscopically on the basis described by Ogoshi (1987). The identified fungi were subcultures on PDA slants and kept at $5^{\circ} \mathrm{C}$ for further studies.

\section{Pathogenicity tests}

These experiments were started with pathogenicity test with 12 pure cultures of $R$. solani (7days - old) toward potato plants. These cultures were obtained from two governorates (EL-shakia and Ismailia). Randomly selected for 6 isolates for every governorate; $R$. solani isolates were artificially inoculated on potato plants under greenhouse conditions.

\section{Preparation of inoculum}

The fungal inoculum was prepared by soaking $100 \mathrm{~g}$ of sorghum grain in $50 \mathrm{ml}$ distilled water in a 500-ml glass bottles overnight, then autoclaved for 60 min at $121^{\circ} \mathrm{C}$ (Mueller et al., 2003). This was followed by inoculating sterilized sorghum with Rhizoctonia 
mycelial plugs (5 $\mathrm{mm}$ in diameter) obtained from one week old potato dextrose agar culture and incubated for 15 days at $27 \pm 2^{\circ} \mathrm{C}$. Plastic pots, $50 \mathrm{~cm}$ diameter, filled with $8 \mathrm{~kg}$ sterilized soil used for soil infested by the pathogen inoculum at rate $10 \mathrm{~g} / \mathrm{kg}$. To ensure good colonization of the pathogen, inoculated pots watered and kept for 48 hours before sowing potato seeds.

\section{Preparation of seed tubers}

Potato seeds, spounta, cultivar (most susceptible and the common grown cultivar in Egypt) according to El-Naggar et al. (2013), were surface sterilized by soaking in sodium hypochlorite $(1 \%)$ for three minutes then in ethyl alcohol $(70 \%)$ for one minute. After that washing several times with sterilized water.

\section{Experimental layout}

Soil (clay and sand 1: 1) were sterilized by using $37 \%$ commercial formalin. One part of the formalin was diluted with nine parts of water. Soil was irrigated with the formalin solution and covered with a polyethylene sheet for 48 hours. Soil was exposed to air for 4 to 5 days until the formalin completely evaporated, according to El-Aziz et al. (2013). Pots $(50 \mathrm{~cm}$ in diameter) were filled with sterilized soil, then inoculated with $R$. solani isolate at a rate of $10 \mathrm{~g} / \mathrm{kg}$ soil and watered for 4 days before planting. The pots were randomly distributed in open field at Experimental Farm, Faculty of Agriculture, Suez Canal University during winter season at ambient temperature, and three pots were used as replicates for each treatment, each replicate contains three plants.

\section{Disease Severity}

Severity of stem canker disease was evaluated using a scale of (0-4) according to Carling and Leiner (1990) after 50 days from sowing. Black scurf disease severity was determined by using 0 5 disease severity grades based on the percent tuber surface showing disease symptoms, according to Ahmad et al. (1995)

\section{Anastomosis group identification by molecular technique}

This experiment was conducted in Biotechnology

Research Center, Suez Canal University during February 2015.

\section{Fungal isolates}

Isolate of $R$. solani from potato tubers (RS No7) were collected from El-Sharkia Governorate (New ELSalhia region) and was the most virulent isolate among 12 isolates on pathogenicity test trial, were chosen to identify Anastomosis group (AG) of this isolate.

The DNA of the fungal isolate was extracted from the freeze-dried powder of mycelium with the Genomic DNA preparation kit (Jena Bioscience).

\section{DNA extraction}

Discs (5-mm-diam), taken from a - 7-dayes-old $R$. solani culture grown on PDA medium, were transferred into $250 \mathrm{ml}$ conical flask containing $100 \mathrm{ml}$ of potato-dextrose broth with shaking at $125 \mathrm{rpm}$ using an orbital shaker (Gallenkamp), at $23^{\circ} \mathrm{C}$ for 4 days. Growing mycelia were harvested by filtration through sterile cloth, washed with sterile deionized water, frozen in liquid nitrogen freeze-dried and stored at $-20^{\circ} \mathrm{C}$.

DNA extracted from $50 \mathrm{mg}$ of mycelial growth using Qiagen Kit was dissolved in $100 \mu$ l of elution buffer. The concentration and purity of the obtained DNA was determined by using Genomic DNA preparation kit (Jena Bioscience). For DNA sample, the concentration was adjusted to $6 \mathrm{ng} / \mu \mathrm{l}$ using TE buffer (pH.8.0); meanwhile the purity reached $90-97 \%$ with ratios between 1.7- 1.8 according to (Sambrook et al., 1989).

\section{PCR amplification}

The internal transcribed spacer (ITS) region of the isolate was amplified using the universal primers

ITS-1 (5' TCC GTA GGTGAA CCT GCGG 3')

ITS-4 (5'TCC TCC GCT TAT TGA TATGC3').

The ITS region of the rDNA and part of DNA template were amplified by PCR reaction: for total volume of $25 \mu \mathrm{l}$ :

$12.5 \mu 1$ Master Mix (Qiagen)

$2 \mu 1$ DNA template $(20 \mathrm{ng} / \mu \mathrm{l})$

$2 \mu 1$ Primer (20 pmole)

$8.5 \mu$ l deionized $\mathrm{H} 2 \mathrm{O}$

The amplification protocol using PCR was carried out as follows:

Denaturation at $94^{\circ} \mathrm{C}$ for $2 \mathrm{~min}$.(one cycle).

35 Cycles, each consists of the following steps:

Denaturation at $94^{\circ} \mathrm{C}$ for $30 \mathrm{~s}$

Annealing at $52^{\circ} \mathrm{C}$ for $30 \mathrm{~s}$

Extension at $72^{\circ} \mathrm{C}$ for $3 \mathrm{~min}$

Final extension at $72^{\circ} \mathrm{C}$ for $10 \mathrm{~min}$. (one cycle)

The sequences were analyzed with BLAST ${ }^{\circledR}$ (Altschul et al., 1997) against the NCBI sequence database (National Center for Biotechnology Information, GenBank) (www.ncbi.nlm.nih.gov/genbank/) to detect similar sequences of known AGs

\section{Gel analysis}

The PCR product was analyzed via agarose gel electrophoresis in $0.5 \mathrm{X} \mathrm{TBE}$ to verify the reaction and to check for contamination. A part is taken of PCR products were checked by electrophoresis on a $1.5 \%$ agarose gel, revealed with ethydium bromide and visualized by UV transillumination according to (Sambrook et al., 1989)

\section{RESULTS}

\section{Isolation and purification of the causal pathogen}

Fungal cultures belonging to $R$. solani were isolated and identified according to morphological and microscopical characters.

Mycelia of all isolates were light brown during early growth and all produced large amounts of aerial hyphae throughout the growth cycle. As cultures aged, their color darkened and most was very dark brown after 21 days. Concentric rings formed on all cultures by day three, but rings tended to disappear as cultures matured and darkened. By day six, sclerotia formed near the edge of the Petri dishes. However, 21 days after growth, sclerotia were scattered randomly about the agar surface as well as in the agar. Individual sclerotia were tan when young, generally dark brown when mature, and up to $1.5 \mathrm{~mm}$ in diameter with clumps up to $5 \mathrm{~mm}$ in diameter

Microscopical examination shows a long mycelium with a dimension of $14.8 \mu \mathrm{m}$. Hyphae produce 
branches at right and acute angles and there is often a septum near the developing branch (Fig. 1).

Pathogenicity tests

Twelve Rhizoctonia isolates were selected from $140 R$. solani isolates according to locations, seasons, and potato infected parts were screened for their pathogenicity toward potato cultivar Spounta in pots plants under greenhouse conditions were conducted in
Experimental in the open field botanical garden, Faculty of Agriculture, Suez canal University during winter season at ambient temperature.

Rhizoctonia diseases on stems were presented as disease index (DI) (Fig. 2).

Potato black scurf disease index using 0-5 scales (Fig. 3).

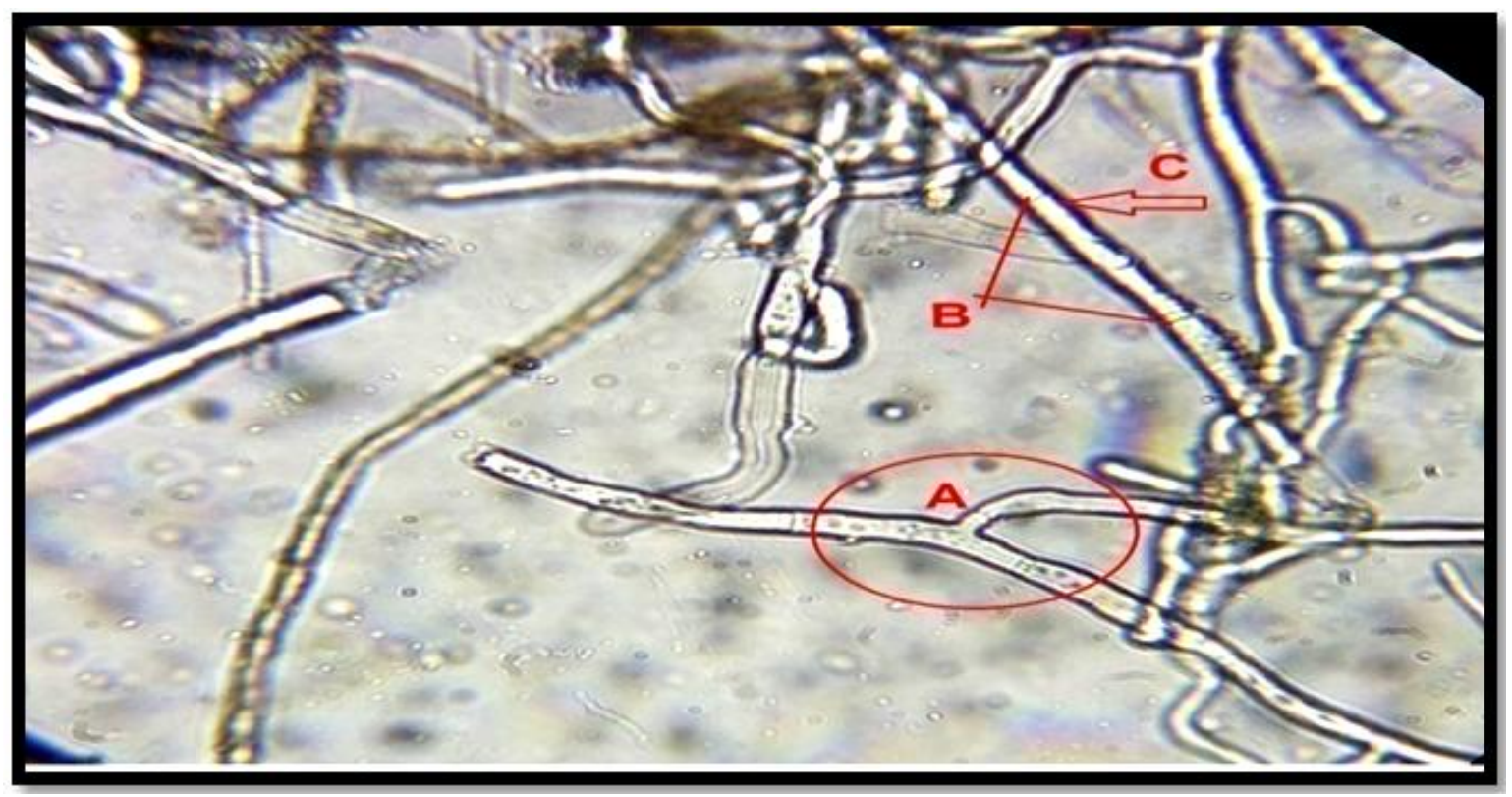

Fig. (1): Morphological characteristics to R. solani under light microscope Branching hyphae (A) Septum (B) Main hyphae (C).

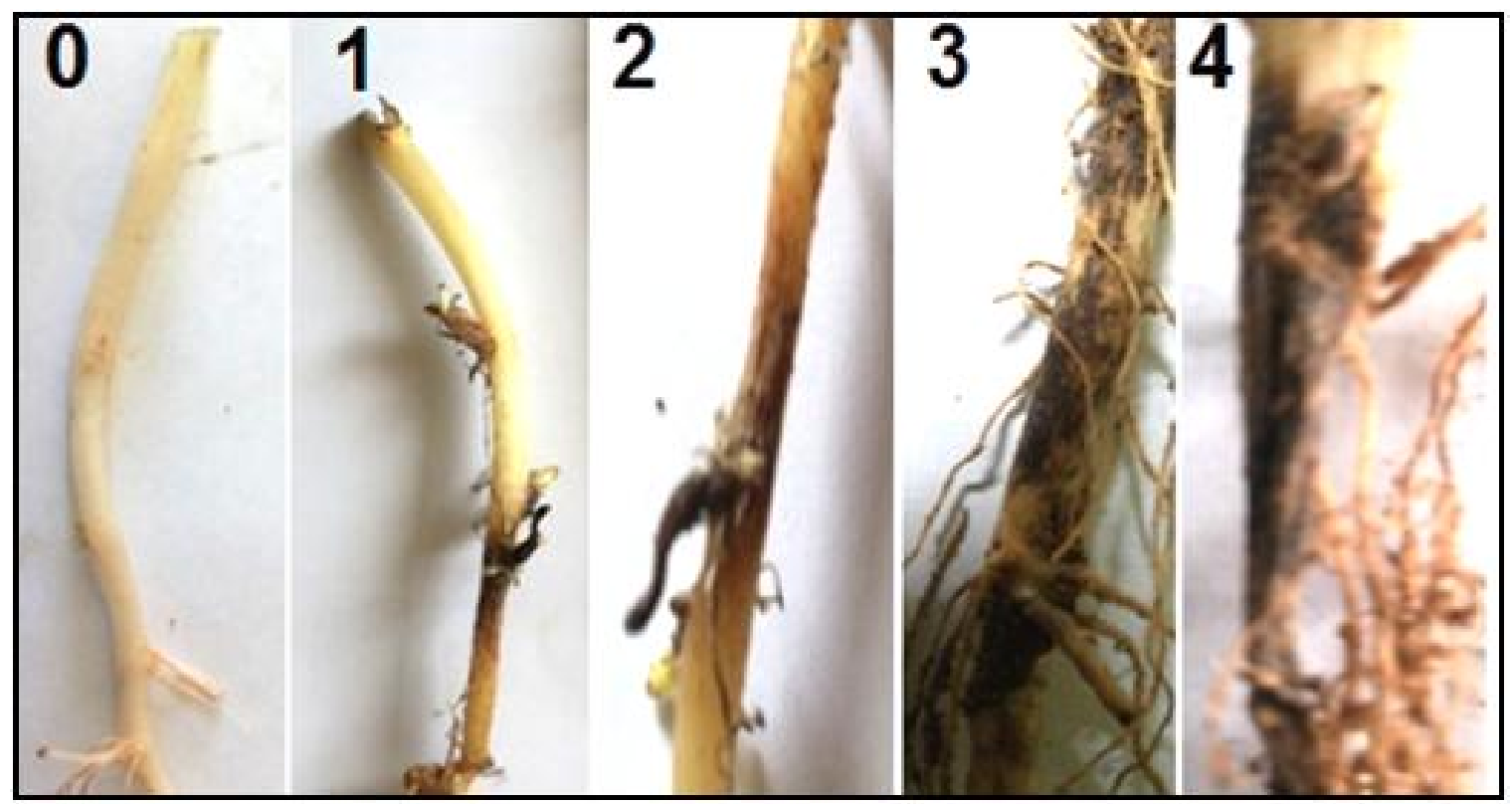

Fig. (2): Stem canker index in potato (0 -4 scales) 


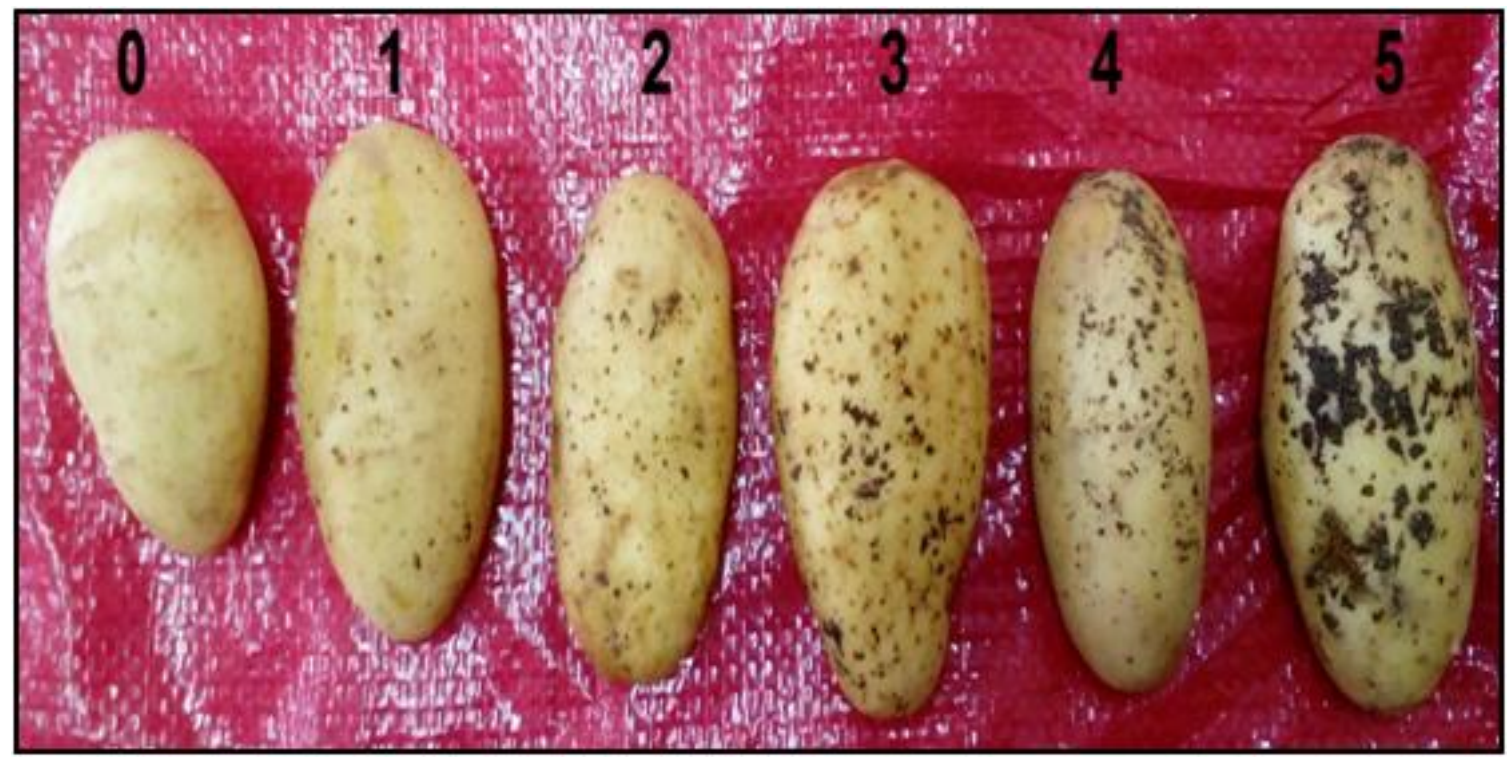

Fig. (3): Black scurf index in potato(0 -5 scales)

During testing the ability of $R$. solani isolates to induce potato Rhizoctonsis, representing data in Fig. (4) show significant differences of potato stem canker and black scurf disease severity. According to disease severity of stem canker and black scurf by $R$. solani isolates under test, isolates classified into three main pathogenic groups:

A- Strong isolates, this group represented by isolate RS7 isolated from ElSharkiya Governorate (New El-
Salhia Region). This isolate was used throughout this investigation.

B- Moderate isolates, this group exemplified by isolates RS6, RS8 and RS10 obtained from Ismailia Governorate (El-Shabab Region).

C- Weak isolates, this group includes three isolates (RS5, RS11, and RS10), isolated from Ismailia and ElSharkiya Governorates, respectively.

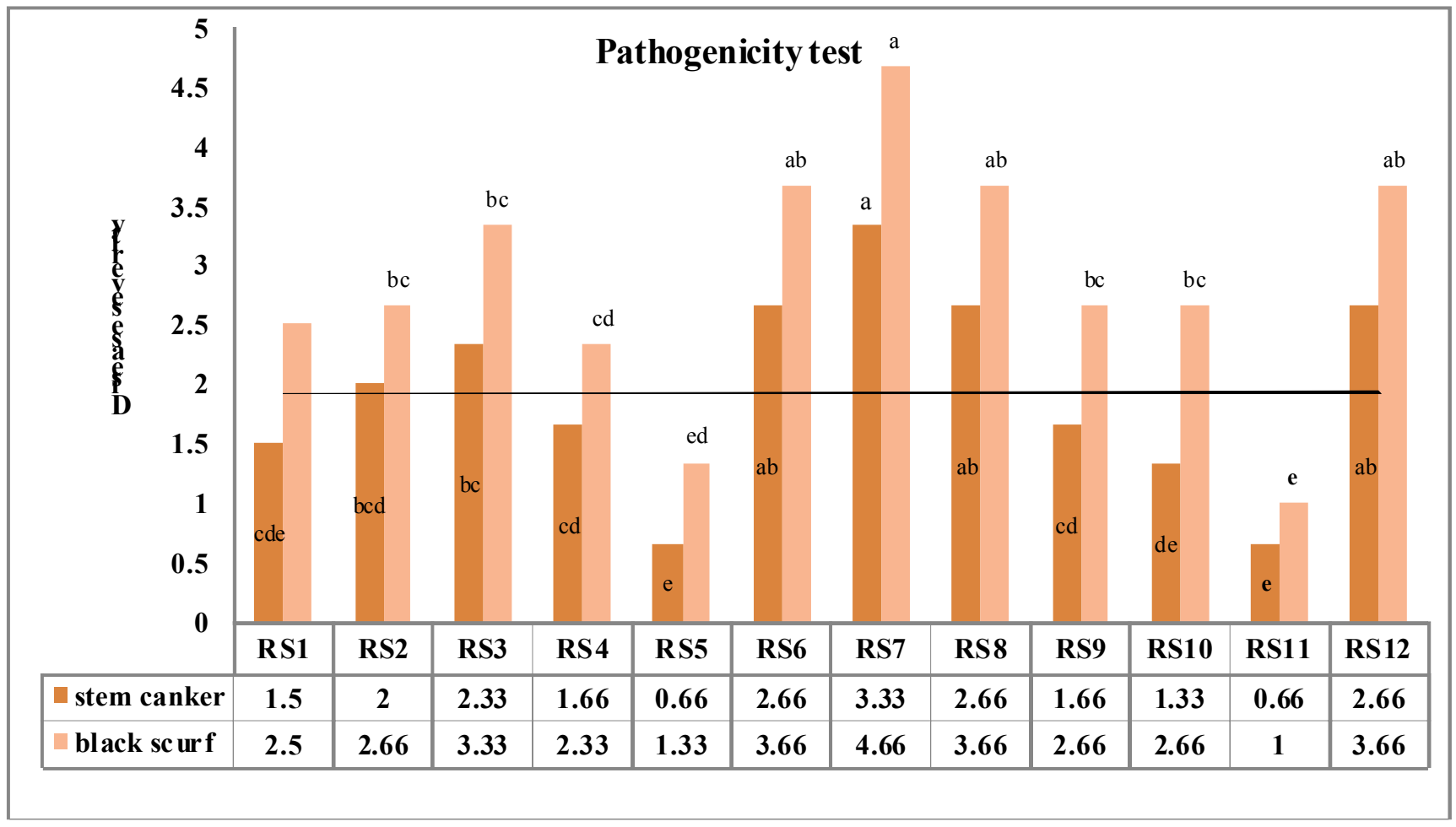

Fig. (4): Pathogenicity test with 12 R. solani isolates on potato plants. Each value represents the mean of 3 replicates

Values followed by the same letter do not differ significantly according to (LSD) least significant difference (P $\leq 0.05)$. 
Anastomosis group identification by specific PCR and sequencing of ribosomal DNA

The resulting data of $R$. solani sequences isolated from potato tubers (RS No7), collected from ElSharkiya (New El-Salhia Region), revealed that a base length of 1169 base.

Sequencing of rDNA of isolate RS7 showed that sizes of the ITS region varied from 680 to 700 base pairs and their sequences were identical $(100 \%)$ in the ITS region.

The resulting data of sequences which analyzed with BLAST ${ }^{\circledR}$ Altschul et al. (1997) against the sequence database National Center for Biotechnology Information, GenBank (NCBI) to detect similar sequences of known AGs. showed that the tested isolate is completely related to AG-3 .

The comparison between sequences registered in GenBank and sequences of RS7 tested isolate showed that the isolate had sequence homology $99 \%$ and $100 \%$ with the referent isolates. ITS sequences of the tested isolate showed $100 \%$ complementarily with representative of anastomosis group 3.

Data illustrated in Figure (5) represent two sequences of $R$. solani AG-3 from GenBank (JATN01000256.1 and JATN01000136.1) were used as references. Nucleotide identity among sequences was determined for anastomosis group identified.

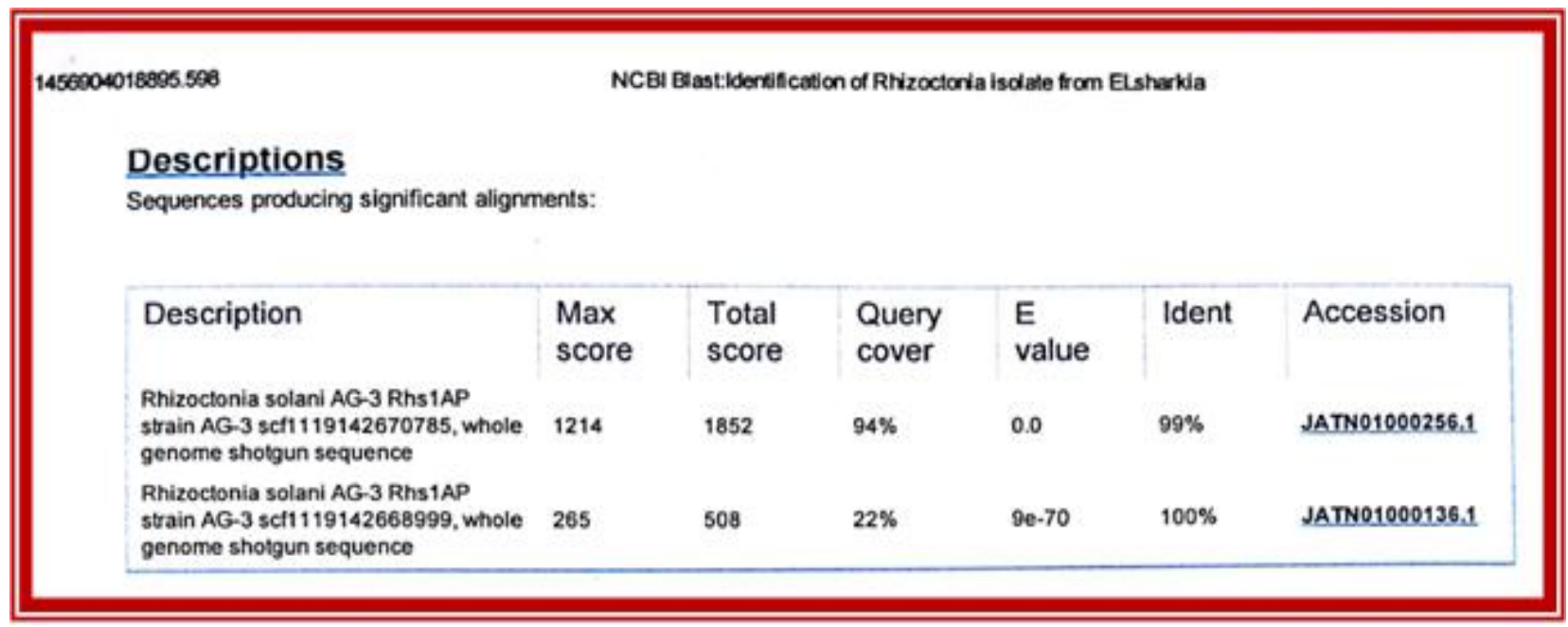

Fig. (5): Two sequences reference of $R$. solani AG-3

The ITS1 - ITS4 regions of the rDNA from the $R$. solani sequences showed high sequence similarity (99-100\%) among them and with two AG-3PT sequences (JATN01000256.1 and JATN01000136.1), respectively from Gen Bank (Fig. 5).

Gel electrophoresis after PCR reaction, the presence of amplified products was tested by running an agarose gel in TAE buffer. DNA bands were approximately 687 base pairs long (Fig. 6).

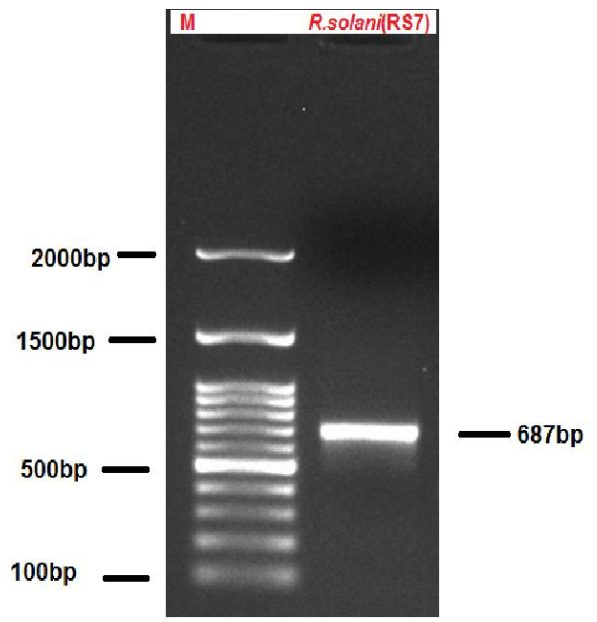

Fig. (6): Gel electrophoresis after PCR reaction to identify AGs of $R$. solani isolate RS7

\section{DISCUSSION}

Increasing importance of the potato crop year after year in Egypt because of its nutritional value, as well as economic value due to the increase of quantity exported from it, especially for the countries of the European Union and Russia. Egypt is the first country on the level of the continent of Africa in the amount of potatoes produced in 2013 (Anonymous, 2013).

Result of pathogenicty test with 12 isolates showed significant differences of potato stem canker and black scurf disease severity, isolates classified into three main groups: Strong isolates, represented by isolate RS7 isolated from El-Sharkiya Governorate (New El-Salhia Region). Moderate isolates, this group exemplified by isolates RS6, RS8 and RS10obtained from Ismailia Governorate (El-Shabab Region).Weak isolates, this group includes three isolates (RS5, RS11, and RS10), isolated from Ismailia and El-Sharkiya governorates, respectively.

Virulence of $R$. solani isolate on potato may be depending on the source of isolates from lesions or sclerotia, as reported by Carling and Leiner (1990). They found height virulence between isolates which isolated from lesions, while low virulence was observed from sclerotia isolates. Virulence of isolates in pathogenicity attributed to difference between (AGs), $R$. solani other than AG3 generally possess low virulence 
against potato. These results agree with several researches (Balkana and Wenham, 1973; Yanar et al., 2005; Khandaker et al., 2011). Some researchers has made it clear that the reason of differences in susceptibility of infection due to the nature of resistance in potato cultivars (Zhang et al., 2016), another researches attributed this to difference in crop hosts (Heremans et al., 2007). While some researchers attributed this to the difference in anastomosis groups (AGs) (Balali et al., 1995; Woodhall et al., 2008; Ferrucho et al., 2012; Yang et al., 2015). As clarified by Truter and Wehner (2004) who found that AG-3 was the most virulent, with isolates from sclerotia on tubers and lesions, on stems more aggressive than those from symptomless tubers or soil. AG-4 and AG-5 caused significantly less disease than AG-3, but none of the AG-7 and AG-8 isolates showed any virulence to potato sprouts.

Rhizoctonia isolates differed among themselves in severity of the infection and the symptoms brought about it, although similar conditions, several studies have indicated that there are significant differences in the ability of $R$. solani isolates on potatoes infection. Even among optimum conditions, this is an indication the role of genetic factors in different virulence (Rubio et al., 1996). Some studies have recorded a vital variation between isolates AG3, in the difference in the growth rate, and the severity of symptoms and seriousness (Carling and Leiner, 1990; Bains and Bisht 1995; Balali et al., 1995).

Rhizoctonia encompass both multinucleate and binucleate species which are furthermore divided into anastomosis groups (AGs). Presently, the multinucleate species of $R$. solani Kuhn (teleomorph: Thanatephorus cucumeris (Frank) Donk.) are divided into 14 anastomosis groups (Tuncer and Eken, 2013): AG-1 to AG-10, AG-BI (Sneh et al., 1991), AG-11 (Carling et al., 1994), AG-12 (Carling et al., 1999), and AG-13 (Carling et al., 2002), this subgroup may differ for pathogenic, biochemical or genetic characteristics (Carling et al., 2002).

Experiments conducted to determine the anastomosis group for aggressive isolate \{isolate RS7 isolated from Sharkiya Governorate (New El-Salhia Region)\} by use Molecular technique (sequence analyses of ribosomal DNA (rDNA) regions) made it clear that they belong to AG3, This result comes from previous approval of the results indicated that the group AG3 are prevail in potato fields (Ferrucho et al., 2012). The results are consistent with what was obtained in Britain by Woodhall et al. (2007) where he focused most of the isolates $(92.6 \%)$ to the group AG3 PT. Similar results were reported in France by Campion et al. (2003), the same results happened in Northern Ireland (Chand and Logan, 1983). In the State of Michigan America, three anastomosis groups were found; these are: AG2-2, AG3 and AG4, AG3 and considered the pathogenic isolates of the potato (Wharton et al., 2007). In warm weather, at Venezuela, Cedeno et al. (2001) found that the percentages were similar for the AG3 and AG2-1. This indicates that agricultural operations are more important than environment in determining the existence of any of the anastomosis groups (Woodhall et al., 2007). In Pakistan, most of the isolates of $R$. solani was the group of potato-growing areas belong to AG3 (81.89\%) and $8.66 \%$ for the group AG5 and 5.5\% for the group AG4 and $1.57 \%$ for the group AG2-1 and $0.79 \%$ for each of the AG1-1A and AG2-2 and AG9 groups (Rauf et al., 2007). On the other hand, some investigators stated that AG3 be more aggressive in cold conditions, such as some parts of North America such as Canada, and Northern and Central Europe (Otrysko et al., 1985; Bandy et al., 1988; Bains and Bisht 1995; Campion et al., 2003). This is in contrary to what is found in Venezuela. Yang et al. (2015) found that AG-3 PT of $R$. solani was the predominant pathogen causing stem canker and black scurf on potatoes in China.

\section{CONCLUSIONS}

Pathogenicity test with 12 isolates of $R$. solani using susceptible cultivar of potato cv. Spounta, revealed that all isolates were pathogenic, with different degrees of pathogenicity (virulent strong, moderate and virulent weak isolates) on potato giving the typical stem canker and black scurf disease symptoms.

Isolate No.RS7 from El-Sharkia Governorate (New El-Salhia Region) was most the virulent isolate and caused the highest stem canker and black scurf disease severity.

Specific PCR-based methods or DNA sequencing of the ITS-rDNA were useful for detection and identification of AGs.

R. solani AG-3PT was associated with potato stem canker and black scurf diseases in Egypt. The adoption of a crop rotation system should consider onhosts of AG-3PT.

\section{REFERENCES}

Ahmad, I., S. Iftikhar, M. Soomro, S. Hameed and S. Khalid (1995). Diseases of potato in Sindh, Pakistan during 1994. CDRI-PSPDP, PARC, Islamabad, Pakistan, p.35.

Altschul, S. F., T. L. Madden, A. A. Schaffer, J. Zhang, Z. Zhang, W. Miller and D. J. Lipman (1997). Gapped BLAST and PSI-BLAST: a new generation of protein database search programs. Nucleic Acids Res, 25(17): 33893402 .

Anonymous (2009). Food and Agriculture Organization of the United Nations. FAO Production, Yearbook, Rome, Italy

Anonymous (2013). Food and Agriculture Organization of the United Nations. FAO Production, Yearbook, Rome, Italy

Bains, P. and V. Bisht (1995). Anastomosis group identity and virulence of Rhizoctonia solani isolates collected from potato plants in Alberta, Canada. Plant Disease, 79(3): 241242.

Balali, G., S. Neate, E. Scott, D. Whisson and T. Wicks (1995). Anastomosis group and pathogenicity 
of isolates of Rhizoctonia solani from potato crops in South Australia. Plant Pathology, 44(6): 1050-1057.

Balkan, H. and H. Wenham (1973). Pathogenicity of potato sclerotial isolates of Rhizoctonia solani to potato shoots. New Zealand Journal of Experimental Agriculture, 1(4): 383-385.

Bandy, B., S. Leach and S. Tavantzis (1988). Anastomosis group 3 is the major cause of Rhizoctonia disease of potato in Maine. Plant Disease (USA), 72(7): 596-598.

Campion, C., C. Chatot, B. Perraton and D. Andrivon (2003). Anastomosis groups, pathogenicity and sensitivity to fungicides of Rhizoctonia solani isolates collected on potato crops in France. European Journal of Plant Pathology, 109(9): 983-992.

Carling, D. and R. Leiner (1990). Virulence of isolates of Rhizoctonia solani AG-3 collected from potato plant organs and soil. Plant Disease, 74(11): 901-903.

Carling, D., R. Baird, R. Gitaitis, K. Brainard and S. Kuninaga (2002). Characterization of AG-13, a newly reported anastomosis group of Rhizoctonia solani. Phytopathology, 92(8): 893-899.

Carling, D., E. Pope, K. Brainard and D. Carter (1999). Characterization of mycorrhizal isolates of Rhizoctonia solani from an orchid, including AG-12, a new anastomosis group. Phytopathology, 89(10): 942-946.

Carling, D., C. Rothrock, G. MacNish, M. Sweetingham, K. Brainard and S. Winters (1994). Characterization of anastomosis group 11 (AG-11) of Rhizoctonia solani. Phytopathology, 84(12): 1387-1393.

Cedeno, L., C. Carrero, K. Quintero, Y. Araujo, H. Pino and R. Garcia (2001). Identification and virulence of anastomosis groups in Rhizoctonia solani Kühn associated with potato in Merida, Venezuela. Interciencia, 26(7): 296-300.

Chand, T. and C. Logan (1983). Cultural and pathogenic variation in potato isolates of Rhizoctonia solani in Northern Ireland. Transactions of the British Mycological Society, 81(3): 585-589.

Cunnington, A. (2008). Developments in potato storage in Great Britain. Potato Research, 51(3-4): 403-410.

El Bakali, A. M. and M. P. Martín (2006). Black scurf of potato. Mycologist, 20(4): 130-132.

El-Aziz, A. R. A., M. A. Mahmoud, M. R. Al-Othman, E. M. El-Sherif and H. El-Marzouky (2013). Differential interaction between isolates of Rhizoctonia solani AG-3 and potato cultivars. African Journal of Microbiology Research, 7(12): 1045-1054.

El-Naggar, M., A. M. Al Rajhi, E. M. Abdelkareem, M. Mahmoud and R. Abdelgany (2013). Biochemical defense mechanism in potato against stem canker and black scurf disease. Asian Journal of Plant Sciences, 12(4): 165.
Ferrucho, R. L., J. M. Cifuentes, P. Ceresini and C. García-Domínguez (2012). Rhizoctonia solani AG-3PT is the major pathogen associated with potato stem canker and black scurf in Colombia. Agronomía Colombiana, 30(2): 204-213.

Fiers, M., C. Chatot, V. Edel-Hermann, Y. Le Hingrat, A. Y. Konate, N. Gautheron and C. Steinberg (2010). Diversity of microorganisms associated with atypical superficial blemishes of potato tubers and pathogenicity assessment. European Journal of Plant Pathology, 128(3): 353-371.

Heremans, B., S. A. Garrido and G. Haesaert (2007). Study of the aggressiveness of Rhizoctonia solani isolates. Communications in Agricultural and Applied Biological Sciences, 72(4): 989

Khandaker, M. M., A. Khair and M. K. A. Bhuiyan (2011). Disease reaction of potato germplasms and true potato seeds against Rhizoctonia solani Kuhn. Bangladesh Journal of Botany, 40(2): 193-196.

Mueller, D., R. Nelson, G. Hartman and W. Pedersen (2003). Response of commercially developed soybean cultivars and the ancestral soybean lines to Fusarium solani f. sp. glycines. Plant Disease, 87(7): 827-831.

Ogoshi, A. (1987). Ecology and pathogenicity of anastomosis and intraspecific groups of Rhizoctonia solani Kuhn. Annual Review of Phytopathology, 25(1): 125-143.

Otrysko, B., G. Banville and A. Asselin (1985). Anastomosis group identification and pathogenicity of isolates of Rhizoctonia solani obtained from tuber-borne sclerotia. Phytoprotection, 66(1): 17-21.

Rauf, C., M. Ashraf and I. Ahmad (2007). Management of black scurf disease of potato. Pakistan Journal of Botany, 39(4), 1353.

Rubio, V., S. M. Tavantzis and D. K. Lakshman (1996). Extra chromosomal elements and degree of pathogenicity in Rhizoctonia solani Rhizoctonia Species: Taxonomy, Molecular Biology, Ecology, Pathology and Disease Control, pp. 127-138.

Sambrook, J., EF. Fritsch and T. Maniatis (1989). Molecular cloning: A laboratory manual (2nd ed.), Cold Spring Harbor Laboratory Press, Cold Spring Harbor, NY, USA. pp 150-266.

Sneh, B., L. Burpee and A. Ogoshi (1991). Identification of Rhizoctonia species: American Phytopathological Society, St. Paul, $\mathrm{MN}$ (EUA).

Truter, M. and F. Wehner (2004). Anastomosis grouping of Rhizoctonia solani associated with black scurf and stem canker of potato in South Africa. Plant Disease, 88(1): 83-83.

Tuncer, S. and C. Eken (2013). Anastomosis Grouping of Rhizoctonia solani and Binucleate Rhizoctonia spp. Isolated from Pepper in Erzincan, Turkey. Plant Protection Science, 49(3): 127-131. 
Wharton, P., W. Kirk, D. Berry and S. Snapp (2007). Rhizoctonia stem canker and black scurf of potato. Extension Bulletin, 2994.

Woodhall, J., A. Lees, S. Edwards and P. Jenkinson (2007). Characterization of Rhizoctonia solani from potato in Great Britain. Plant Pathology, 56(2): 286-295

Woodhall, J., A. Lees, S. Edwards and P. Jenkinson (2008). Infection of potato by Rhizoctonia solani: effect of anastomosis group. Plant Pathology, 57(5): 897-905.

Yanar, Y., G. Y1lmaz, I. Cesmeli and S. Coskun (2005). Characterization of Rhizoctonia solani isolates from potatoes in Turkey and screening potato cultivars for resistance to AG-3 isolates. Phytoparasitica, 33(4): 370376.

Yang, Y., C. Zhao, Z. Guo and X. Wu (2015). Anastomosis group and pathogenicity of Rhizoctonia solani associated with stem canker and black scurf of potato in China. European Journal of Plant Pathology, 143(1): 99-111.

Zhang, X. Y., H. L. Huo, X. M. Xi, L. L. Liu, Z. Yu and J. J. Hao (2016). Histological observation of potato in response to Rhizoctonia solani infection. European Journal of Plant Pathology, 145(2): 289-303.

\section{اختبار القدرة المرضية وتحديد مجموعة الالتحام للفطر ريزوكتونيا سولانى المسبب لمرض تقرح الساق

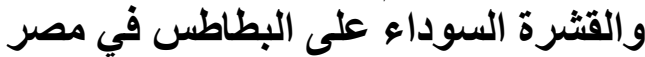

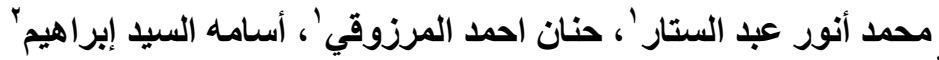

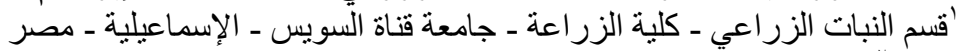

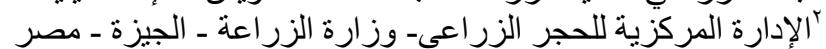

يعتبر مرض تقرح الساق والقشرة السوداء المتسبب عن الفطر Rhizoctoni solani من أخطر الأمراض الفطرية التي تؤدى إلى إلى إلى

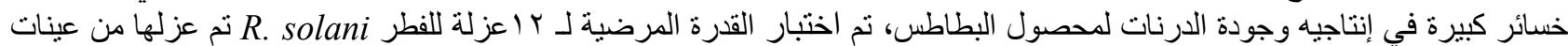

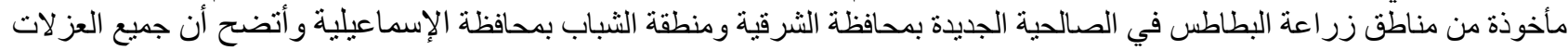

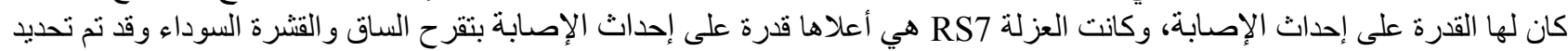

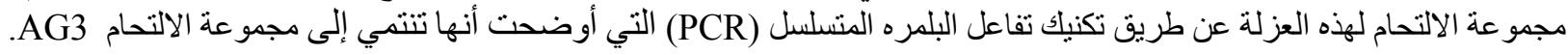
كلمات مفتاحية: تقرح الساق ـ القشرة السوداء ـ القدرة المرضية ـ مجمو عة الالتحام ـ تفاعل البلمره المتسلسل (PCR). 